\title{
THE SCHOOL HEALTH SERVICE IN BRITAIN
}

$\mathrm{T}$ HE School Health Service is fifty years old. In the half-century of its existence there have been remarkable changes in the health of school children, and in the pattern of illnesses affecting them. Both boys and girls to-day are taller and heavier, better clad, better shod and cleaner. They reach physical maturity earlier and may expect to live twenty years longer. In sharp contrast to the conditions of malnutrition found only too commonly 50 years ago, medical attention is now being drawn towards an increasing number of school children who are too fat.

The annual report* of the Chief Medical Officer presents these facts and discloses among other vital statistics that the killing and erippling diseases prevalent at the turn of the century-tuberculosis, rickets and rheumatism--have been practically eliminated. The remaining causes of crippling and other forms of handicap are now mainly congenital or hereditary in origin. Accidents still kill twice as many children as die from disease, and road accidents are responsible for half the deaths recorded. Boys are more liable to death on the road than girls; leaving school in the afternoon is one of the most risky periods of the day.

Nearly 250,000 children were found to have verminous heads in 1957. This is about 4 per cent of the total school population. "This condition is preventable and there is seldom any excuse for it", says the report. "It is essentially a family problem, children being infested and re-infested by adults". The current question of smoking and its relation to lung cancer provides "a striking example of the need

* The Health of the School Child: Fifty Years of the School Health Service. (Report of the Chief Medical Officer of the Ministry of Education for the years 1956 and 1957.) $\mathrm{Pp}$. $\mathrm{i}+220+12$ plates. (London: H.M. Stationery Office, 1958.) $10 s$. 6 d. net. for boys and girls, while still at school, to be taught something about healthy living-by example, perhaps, more than by precept. In spite of all that has been said and written about the close connexion between the two, many children still smoke cigarettes". A recent inquiry carried out at a mixed secondary modern school in the Isle of Wight disclosed that about a third of the boys and 15 per cent of the girls were regular smokers.

The incidence of dental decay has increased in the past few years among school children, and is due "probably to the greater amount of sweets and confectionery eaten since the end of sweet rationing". Fluoridation of water supplies probably offers the best hope of reducing this incidence, "but large scale benefits from this measure can hardly be expected for several years".

One consequence of the changing pattern of illhealth in childhood is that school health service staffs now devote more attention to children who are emotionally disturbed, or who suffer from some handicap which threatens to have a retarding effect on school progress from a psychological cause.

There is also the challenge of the delinquent school child which cannot be ignored by the school health service. The number of children charged before the juvenile courts has risen from 13,000 in 1913 to 38,000 in 1956. It is right, says the report, that the school health service should concern itself with the problem and co-operate with the other agencies involved. In 1957 more than six and a half million children attending about 30,000 maintained and assisted schools were covered by the service. More than two million have a periodical inspection during the year.

\section{INCENTIVES IN THE BUILDING INDUSTRY}

\begin{abstract}
A
RECENT Building Research Station report* on incentives in the building industry shows that bonus schemes have an important contribution to make to building efficiency. The maximum benefit can only be derived, however, if they are integrated into a rational pattern of management. The report enumerates principles on which an incentive scheme should be based as well as the rnethod of operation if it is to be successful.

Operation targets, coupled with a recording system giving operation costs, should be used whenever possible. The operations should be the visual stages of work, of about one week's duration, and continuous jobs with no hold-ups for other trades.

The scheme should be designed to suit individual needs and local conditions. This calls for flexibility in targets to suit the local productivity of labour and

* Department of Scientiflc and Industrial Research: Building Research Station. National Building Studies Special Report No. 28 : Incentives in the Building Industry. By Alison Entwistle and W. J.
Reiners. Pp.iv + 43. (London: H.M. Stationery Office, 1958.) $3 s$. net.
\end{abstract}

the distribution of bonus payments. The operatives on each site should decide the method of sharing within the bonus group or gang. It is necessary to safeguard the quality of work by making site staff independent of production bonus and improving site supervision of quality.

A number of conclusions were reached about the methods of operation of an incentive scheme. Accurate and well-balanced targets should be maintained by the systematic use of cost information from all the firm's sites and by close consultation with its site staff. The incentive effect of a scheme is greatest when it is given a central position in the organization of the firm, especially if administered by the contract management side. There should be close liaison between estimating and the fixing of target bonus-rates. The principles of the scheme should be kept simple and explained to the operatives so that they can calculate their own bonuses. The bonus units are small gangs. 